\title{
Dermoscopy assisting the diagnosis of mycetoma: case report and literature review
}

\author{
Larissa Montanheiro dos Reis ${ }^{1}$ \\ Fernando da Cunha Zillo \\ Lincoln Helder Zambaldi Fabricio ${ }^{1}$
}

\author{
Brunno Zeni de Lima ${ }^{1}$ \\ Camila Makino Rezende ${ }^{1}$ \\ Camila Araujo Scharf Pinto ${ }^{1}$
}

Abstract: Mycetomas are a chronic skin infection characterized by perilesional edema, formation of sinus tracts, and discharge of purulent or seropurulent exudate containing grains. This report aims to demonstrate the clinical diagnosis (by dermoscopy) of a skin lesion that initially bared no clinical features of a mycetoma.

Keywords: Acremonium; Dermoscopy; Mycetoma

Mycetoma is a chronic infection of the skin characterized by perilesional edema, formation of sinus tracts, and discharge of purulent exudate containing grains. ${ }^{1}$ It is confirmed by pathology and culture. ${ }^{2,3}$ This report outlines the case of a clinically nonspecific cutaneous lesion, in which the dermoscopy led to the clinical hypothesis.

A 47 year-old female, from the urban area of Rondonia, was referred to the Dermatology Service of a Hospital in Curitiba, with an asymptomatic 4 year-old lesion on her left foot that underwent spontaneous resolution. Three months before, a new lesion had appeared in the same area, with serosanguineous drainage. Examination revealed a violate nodular lesion, scaly and rough, on the base of the third left toe (Figure 1). Upon dermoscopy, (DermLite ${ }^{\circledR}$, Gen, INC.) yellowish and white structures were identified (Figures 2 and 3). Excisional biopsy was performed, pathology with PAS stain showed suppurative granuloma with grains

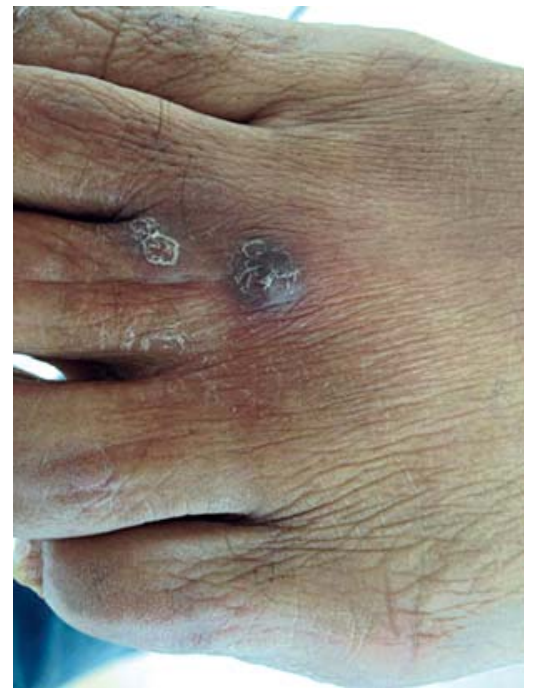

Figure 1:

Papular-nodular lesion, violet to brown, slightly scaly, rough and dull on the base of the third left toe

\footnotetext{
Received on 24.07.2013.

Approved by the Advisory Board and accepted for publication on 26.08.2013.

Work performed at the Hospital Universitário Evangélico de Curitiba - Faculdade Evangélica do Paraná (HUEC-Fepar) - Curitiba (PR), Brazil.

Conflict of interest: None

Financial funding: None

Faculdade Evangélica do Paraná (Fepar) - Curitiba (PR), Brazil.

Private clinic - Curitiba (PR), Brazil.

(C)2014 by Anais Brasileiros de Dermatologia
} 


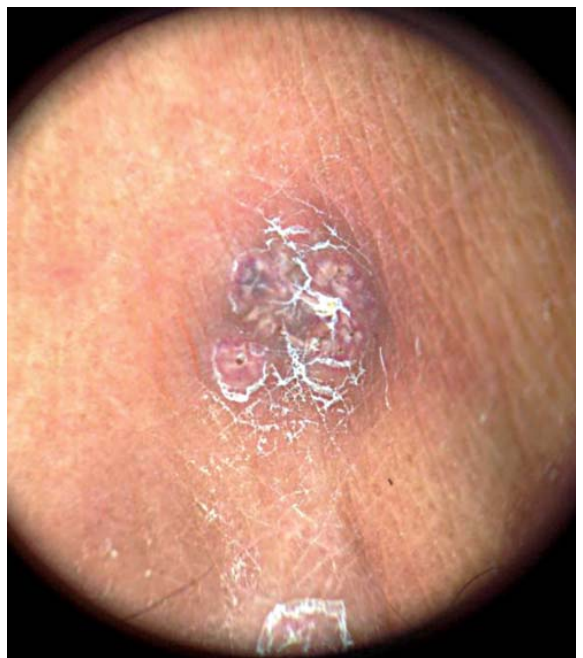

FIGURE 2:

Upon dermoscopy, whitish and yellowish structures

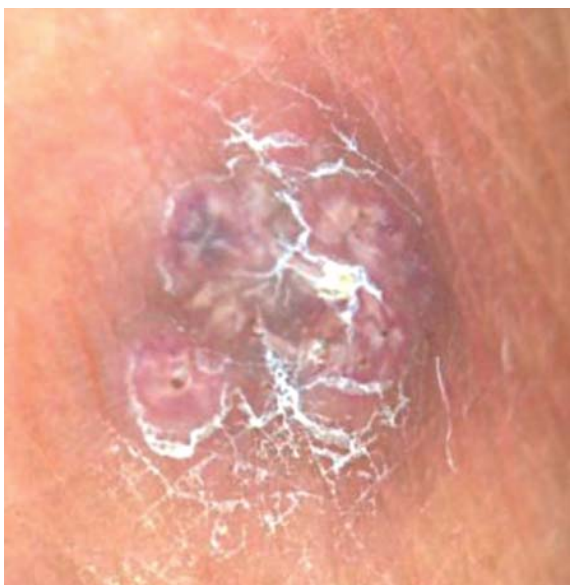

FIGURE 3:

Dermoscopy (higher magnification)

\section{REFERENCES}

1. Ruiz LR Micetomas Eumicóticos. In: Zaitz C, Campbell I, Marques SA, Ruiz LRB, Framil VMS. Compêndio de Micologia Médica. 2 ed. Rio de Janeiro: Guanabara Koogan; 2010. p.206-11.

2. Sampaio SA, Rivitti EA. Micoses profundas. In: Sampaio SA, Rivitti EA. Dermatologia. 3 ed. São Paulo: Artes Médicas; 2008. 723-52.

3. Hoffmann Cde C, Danucalov IP, Purim KS, Queiroz-Telles F. Infections caused by dematiaceous fungi and their anatomoclinical correlations. An Bras Dermatol. 2011;86:138-41.

4. Bastos CA. Indicações não tradicionais de dermatoscopia. Surg Cosmet Dermatol. 2012;4:203-5.

5. Tedesco-Marchese LM, Castro RM, Lacaz CS, Cucé LC, Salebian A, Sotto MN. Acremoniose cutânea: relato de um caso. An Bras Dermatol. 1987;62:25-30.

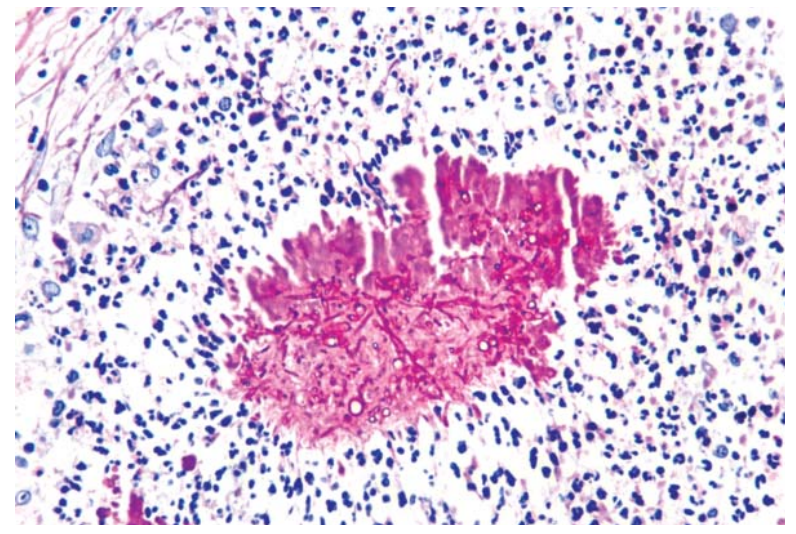

FIGURE 4: Suppurative granuloma containing grains and hyaline septate hyphae)

and hyaline septate hyphae (Figure 4). The tissue culture revealed Acremonium sp, confirming the diagnosis of Eumycetoma. The authors established an adjunctive therapy with Itraconazole $100 \mathrm{mg}$ PO bid. The patient remains in remission.

It is known that dermoscopy improves diagnostic accuracy in pigmented lesions. Nowadays, its application is also extending to diagnostic reports of skin infections, as well as to follow-up benign neoplasms. ${ }^{4}$ As mycetomas are usually clinically evident, there are no studies of their typical features on dermoscopy. However, in uncertain cases, the method is being increasingly applied in clinical practice. ${ }^{5}$

\author{
MAILING ADDRESS: \\ Camila Araujo Scharf Pinto \\ Alameda Carlos de Carvalho, 1652 \\ 80730 -200 - Batel - Curitiba - PR \\ Brazil \\ E-mail:kmischarf@gmail.com
}

How to cite this article: Reis LM, Lima BZ, Zillo FC, Rezende CM, Fabricio LHZ, Pinto CAS. Dermoscopy assisting the diagnose of a Mycetoma: case report and literature review. An Bras Dermatol. 2014;89(5):832-3. 